\title{
Ser and estar from the Cognitive Grammar perspective
}

\author{
Alejandro Castañeda Castro \\ Universidad de Granada, Spain \\ acastro@ugr.es
}

\begin{abstract}
This article explores the various uses of ser and estar in Spanish based on the assumptions of Cognitive Grammar (CG). The application of certain concepts of this model to the description of the attributive and non-attributive values of ser and estar allows us to identify a unifying thread that facilitates an integrated description of each use. These concepts and theoretical instruments include grammaticalization through attenuation, active zone, profile/base distinction, and dependency relation through correspondences, among others.

In accordance with the symbolic conception of grammar characteristic of CG, we defend the idea that in their attributive and non-attributive uses both ser and estar are signs in which a basic semantic structure present in all the values can be recognized, although with different emergent nuances in specific constructions facilitated by different processes of metonymic extension.

The main argument of this paper is that, in the ser/estar opposition, the marked element is estar as it contains a stative-episodic component that, be it in the foreground of the profile or the background of the base presupposed by this verb, is present in all its uses, locative, attributive, as an auxiliary in progressive periphrasis and in adjectival passive constructions. Ser, however, is a copulative verb by default, and may be associated with the notion of identification or correspondence in all its attributive uses and takes on predicative nuances both in its use in locations of event nouns and as an auxiliary in passives.
\end{abstract}

Keywords: cognitive grammar, attributive, non-attributive, ser, estar 


\section{Resumen}

En este artículo se ofrece una aproximación a los distintos usos de ser y estar en español basada en los supuestos de la Gramática Cognitiva (GC). La aplicación de ciertos conceptos de este modelo a la descripción de la variedad de valores atributivos y no atributivos de ser y estar permite reconocer un hilo conductor que facilita una descripción integrada de unos usos y otros. Entre tales conceptos e instrumentos teóricos, destacan los de gramaticalización por atenuación, zona activa, distinción perfil/base, y relación valencial mediante correspondencias.

De acuerdo con la concepción simbólica de la gramática propia de la GC, se defiende la idea de que tanto ser como estar, en sus usos atributivos y no atributivos, constituyen signos en los que debe reconocerse una estructura semántica básica presente en todos los valores, aunque con distintos matices emergentes en diferentes construcciones facilitados por distintos procesos de extensión metonímica.

El argumento principal de este trabajo es que, en la oposición ser/estar, el elemento marcado es estar, pues contiene un componente estativo-episódico que, ya sea en el primer plano del perfil o en el segundo plano de la base presupuesta por este verbo, está presente en todos sus usos locativos, atributivos, como auxiliar de perífrasis progresiva y en las construcciones pasivas adjetivales. Por su parte, ser, verbo copulativo por defecto, puede asociarse a la noción de identificación o correspondencia en todos sus usos atributivos y se reviste de matices predicativos tanto en su uso en localizaciones de nombres de evento como de auxiliar en pasivas.

Palabras clave: gramática cognitiva, atributivo, no atributivo, ser, estar

\section{0 . Content of this article}

This paper is organized as follows: first, in section 1, we will review some of the descriptions of the ser/estar opposition proposed by previous researchers, especially in reference to their attributive values, and highlight some of the questions and doubts that they give rise to; secondly (section 2.1), we will introduce some of the notions and basic instruments of CG (profile/base distinction, grammaticalization through attenuation, active zone, complex categories, subjectification, etc.) that will be applied in the description of the values of ser and estar; finally, in section 2.2, we will attempt to describe the different values of ser and estar in order to present an approach to these verbs that is as integrative as possible. 


\section{Attributive uses of ser and estar. Alternative explanations}

Ser has traditionally been associated with concepts such as "permanent", "intrinsic" or "essential" and estar with those of "transitory", "extrinsic" or "accidental". However, there are many examples that do not conform to these rules such as: Esta crisis es

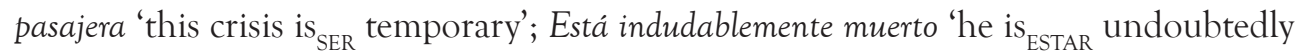
dead' or Polonia está en Europa y es miembro de la Unión Europea 'Poland is ${ }_{\mathrm{ESTAR}}$ in

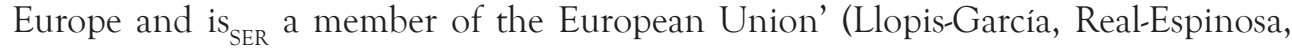
Ruiz Campillo, 2012). This traditional ser/estar distinction has therefore been found lacking and current research tends to focus on three main types of approach, especially in relation to their attributive uses: (1) those based on the type of predicate with which each verb is associated, (2) those that distinguish between the two verbs on the basis of the presuppositional load corresponding to each and (3) those based on identification of the functions with which each is associated.

We will review each of these approaches before addressing the problem from the standpoint of CG.

\subsection{Types of predicates and ser and estar}

We will begin by looking at the approach based on types of predicate. Various different types of predicate have been considered important in clarifying the distinction between ser and estar (see Gumiel Molina 2008). Although different authors use different names to describe them, they are clearly part of the same family:

1. Individual level predicates, that do not involve change, that are conceived as spatially and temporally unbounded, that designate stable or inherent properties and lack internal temporality (inteligente 'intelligent', azul 'blue', cuadrado 'square', universitario 'university (as an adjective)', masculino 'male', etc.) combine with ser. Stage level predicates, that involve change, that are conceived as spatially and temporally limited, that designate transitory properties and have internal temporality combine with estar (cansado 'tired', maduro 'ripe', tumbado 'lying down', contento 'pleased', etc.). This proposal is based on the distinction made by Carlson (1977) and defended among others by Leonetti 1994 and Fernández Leborans 1999.

2. According to an aspectual approach, imperfective predicates (alto 'tall', inteligente 'intelligent', blanco 'white', portátil 'portable', etc.) combine with ser and perfective predicates (abierto 'open', perdido 'lost', dormido 'asleep', quieto 'still', etc.) with estar (Luján, 1981). 
3. Also on the basis of an aspectual distinction, bounded predicates (cansado 'tired', seco 'dry', contento 'pleased', abierto 'open', etc.), or those that correspond to situations which are represented as aspectually bounded, combine with estar and non-bounded predicates (alto 'tall', grande 'big', tierno 'tender', ancho 'wide', rojo 'red', etc.), that correspond to situations that are represented as aspectually non-bounded, combine with ser (Marín, 2004).

4. With regard to a fourth criterion, intersective predicates (portátil 'portable', nacional 'national', doméstico 'domestic', etc.) combine with ser and subsective predicates (pequeño 'small', delgado 'thin', caliente 'hot', etc.) with estar (Romero 2009) ${ }^{1}$. According to Romero, some adjectives, such as relational adjectives, are always interpreted intersectively and therefore are always used with ser, while other adjectives are sometimes interpreted intersectively and sometimes subsectively and may be used with both ser and estar.

5. Another approach, related to those mentioned above, distinguishes between classifying predicates, which combine with ser; and temporally anchored predicates, which combine with estar (Escandell and Leonetti, 2002): Este

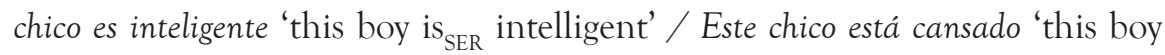
is ${ }_{\text {ESTAR }}$ tired'.

6. Finally, non-scalar (non-gradable relational) predicates such as semanal 'weekly', telefónico 'telephone (as an adjective)', húngaro 'Hungarian', doméstico 'domestic', etc., or non-bounded scalar predicates (gradable without limits from which they can be applied to an object) such as pequeño-grande 'smallbig', ancho-estrecho 'wide-narrow', gordo-delgado 'fat-thin', largo-corto 'long-short', bueno-malo 'good-bad', fácil-difícil 'easy-difficult' combine with ser, while bounded scalar predicates (with a limit from which they can be applied even if it is lower -húmedo 'wet', cansado 'tired', torcido 'twisted', inclinado 'leaning'-, higher -seco 'dry', recto 'straight', harto 'fed up'- or both -lleno 'full', vacio 'empty', aburrido 'bored', cansado 'tired', inclinado 'leaning', etc.-) combine with estar. These notions were applied by Gumiel and Pérez Fernández (2012) based on proposals made by Husband (2012).

1 An intersective adjective is one that, when combined with a noun, gives rise to the designation of the set of things that constitutes the intersection of the set of things denoted by the noun and the set of things denoted by the adjective: un himno nacional [a national anthem] designates the set of things that belong simultaneously to the set of things called himno [anthem] and the set of things called nacionales [national]. A subsective adjective is one that, when combined with a noun, does not give rise to an intersective reading because it is not used by itself to designate a type or category. Una mosca grande [a big fly] does not denote an object that belongs to the type mosca [fly] and the type cosa grande [big thing] because flies are not big things. In this case, grande [big] is used to bound, within the set of flies, those which are big relative to the average size of the insects. 
Some of the approaches based on the type of predicate (Gumiel and Pérez Fernández, 2012; Zagona 2015) view the selection of either ser or estar in their attributive uses as a syntactic reflection of the alternation of features (perfective/nonperfective, bounded/non-bounded, etc.) present in other elements of the sentence. In this sense, ser and estar in their attributive uses are syntactic elements that have no meaning in themselves and that appear in association with the aspectual characteristics of the adjectives with which they combine. Some adjectives can be interpreted either as bounded or non-bounded depending on the particular case (Es pequeño 'it is SER $_{\text {small'/ }}$

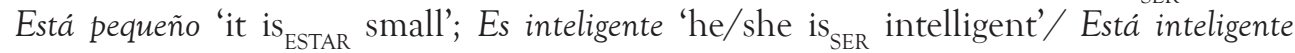

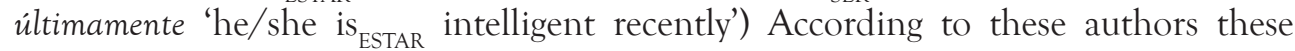
adjectives cannot be regarded as bounded or non-bounded merely on the basis of the verb with which they are combined, but rather because when they are actualized in the utterance, some type of projection or concordance comes into effect that results in the selection of one copula or the other.

In fact, the verbs ser and estar convey their own semantic configuration which they impose on the clause of which they form the head. Not admitting this, as occurs in these approaches, leads to a formal apparatus and a set of morphosyntactic assumptions of projection of semantic features or syntactic functions that is highly onerous from the descriptive point of view and does not lend itself to presentation for teaching purposes.

One of the problems of characterising estar as a copula associated with spatiotemporally anchored predicates, present in most of these distinctions in one form or another, is that ser can be anchored temporally with verb tenses and bounded with perfective tenses and can also be situated spatially: Antonio habia sido camionero en

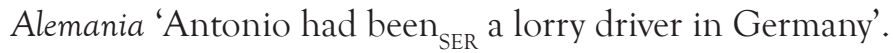

Furthermore, the fact that classificatory or individual level adjectives, such as inteligente 'intelligent', francés 'French' or alto 'tall', can combine with estar ( $\mathrm{La}$

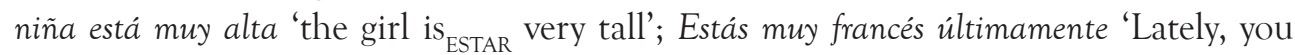
$\operatorname{are}_{\text {ESTAR }}$ very French', Los alumnos estuvieron muy inteligentes ese dia 'the pupils were ESTAR $_{\text {. }}$ very intelligent that day' can be explained in this kind of description by means of the concept of grammatical "coercion" (Escandell and Leonetti 2002), by which combination with estar forces the spatiotemporal interpretation of adjectives which, in the default option, have classificatory features. Gumiel (2008: 3) reminds us that coercion is easier with some adjectives than others and is determined by the type of subject: La charla estuvo muy inteligente 'the talk was ESTAR $_{\text {very intelligent' is incorrect }}$ while El conferenciante estuvo muy inteligente 'the speaker was ${ }_{\mathrm{ESTAR}}$ very intelligent' is perfectly acceptable; similarly La casa está grande 'the house is ESTAR $_{\text {big' is incorrect }}$

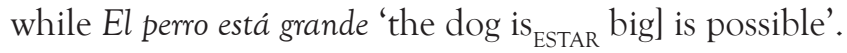


Finally, the main problem of these characterizations based on the type of predicate with which ser or estar combines is not only that many adjectives, probably most, can be understood as belonging to one type or another precisely when combined with ser or estar (es azul 'it is SER $_{\text {blue' / está azul 'it is }}$ ESTAR blue'; es maduro 'it/he is SER $_{\text {f }}$

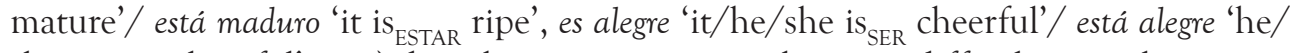
she is $s_{\text {ESTAR }}$ cheerful', etc.), but that in some cases, the most difficult to explain using this approach, it happens that relative, scalar, non-bounded adjectives such as ácido 'sour, tart' or dulce 'sweet', besides being combinable with estar in sentences like las manzanas están ácidas y dulces 'apples are ESTAR $_{\text {tart }}$ and sweet', are not reinterpreted as bounded, perfective, spatiotemporally anchored or state predicates but as stable, objective, imperfective, individual level properties that are not aspectually bounded or spatiotemporally anchored. It is clear, for example, that, in the manzanas 'apples' example, they are describing a general characteristic of this type of fruit, rather than referring to one specific apple or set of apples.

\subsection{Presuppositional load of ser and estar}

The second descriptive criterion (J. Falk, 2014; Clement, 1988; Marín, 2004 and, from a discursive viewpoint, Maienborn, 2005) concerns the presuppositional load, the basis for comparison or norm of reference applied when we use ser or estar. Two of the most recent versions of this approach are Gumiel-Molina, Moreno-Quibén and Pérez-Jiménez (2015) and, to a large extent, Romeu (2015). Gumiel-Molina, MorenoQuibén and Pérez-Jiménez (2015) suggest that the key distinction between attributives with ser and with estar is the distinction between the relative or absolute interpretation of gradable adjectives that combine with these verbs. By "relative interpretation" the authors mean that which involves comparison of the entity to which the subject refers with other entities to establish the standard or reference point relative to which to determine the presence of a certain property (as in El niño es fuerte 'the boy is SER $_{\text {R }}$ strong'-in comparison to the average strength of other boys-), and by "absolute interpretation" they mean that which does not involve comparison with other entities distinct from the subject, but rather comparison with other situations or stages that

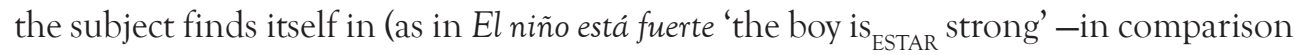
to the average strength shown by the boy on a number of previous occasions-). The authors explain that aspectual and temporal characteristics (such as the imperfective character or persistence in time of attributives with ser or the perfective or episodic character of attributives with estar) derive from the absolute or relative character of the interpretation of the adjective by means of pragmatic inferences. These inferences are based, on the one hand, on the reasoning that if we predicate a property of an individual in comparison to other individuals we presuppose that the degree to which this property occurs in that individual is homogeneous and constant and, on the other 
hand, on the idea that if we predicate a property of an individual in comparison to other manifestations of that same individual we imply that that property is temporally limited.

Romeu (2015) proposes a characterization of the two verbs for both attributive and locative uses, formalized in terms of their generativist root. This way of distinguishing between them is also inspired by the idea that ser and estar convey what could be defined as a different presuppositional load. According to the author, estar, the marked element of the opposition, with a more complex structure, lexicalizes a disjoint modification in which a state is expressed, while also taking into account its relation (which may or may not be of a temporal nature) to a second state; whilst ser, on the other hand, alludes to a state without taking into account its relation to another state because it lexicalizes a conjoint modification. Using this approach it is unclear to what extent permanent locations such as La Alhambra está en Granada 'the Alhambra is $_{\text {ESTAR }}$ in Granada' can convey or presuppose a relation to another location or how to explain cases such as Los pasteles de chocolate están irresistibles 'the chocolate cakes are $_{\text {ESTAR }}$ irresistible', in which it is impossible to identify a different state that acts as a counterpoint to the one described.

As discussed below, this norm of reference or this other situation that is taken into account or is presupposed for ser or for estar, as the case may be, can be expressed in CG in terms of the profile/base opposition. The distinction between these two planes of representation will be crucial to avoid numerous descriptive pitfalls. In addition, the idea of 'stage' associated with estar involves that other situation that serves as a reference. A stage, by definition, presupposes a process (composed of that and other complementary stages) of which it forms a part.

\subsection{Functional associations of ser and estar}

A third type of explanation is the functional explanation (See Molina Redondo and Ortega Olivares (1987), Matte Bon (2000) or Silvagni (2013)). Figure 1 shows a schema reflecting a functional classification, based in part on Silvagni, of the most important uses of these two verbs. 
Figure 1: Some functional values of ser and estar.

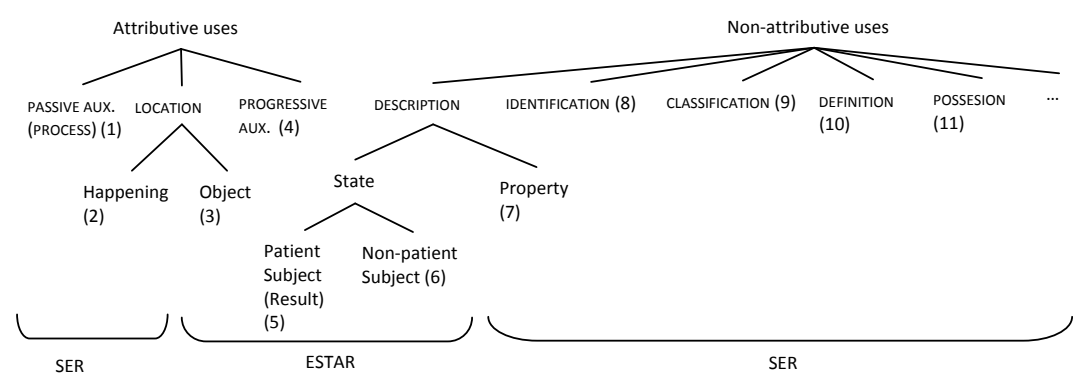

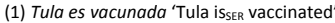
(2) La fiesta de Tula es aquí 'Tula's party is $\mathrm{SER}_{\mathrm{R}}$ here'
(3) Tula está en su cama 'Tula is ESTAR on her bed'
(4) Tula está comiendo 'Tula is $\mathrm{S}_{\mathrm{SER}}$ eating'
(5) Tula está vacunada 'Tula is SESTAR vaccinated'

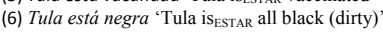
(7)Tula es blanca 'Tula is $\mathrm{SER}_{\mathrm{SER}}$ blanca'
(8) Tula es ese perro 'Tula is $\mathrm{S}_{\mathrm{SER}}$ that dog'
(9) Tula es un bichón maltés 'Tula is $\mathrm{SER}_{\mathrm{SE}}$ a Maltese'

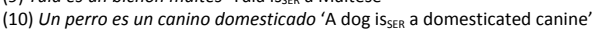
(11) Tula es de mi hija 'Tula is $\mathrm{SER}_{\mathrm{R}}$ my daughter's'

Apart from the functions included in Figure 1, descriptions conceived from a notio-functional viewpoint may be conceived with a greater degree of specification: (ser to attribute professions, provenance, material, etc.; estar to attribute physical state or mood, posture, etc.). This raises the question as to the right degree of abstraction, but these descriptions are also problematic in that in many cases these notions and functions do not help to discriminate between the two verbs. For example, the function of location could be related to estar in cases such as La casa está en la playa 'the house

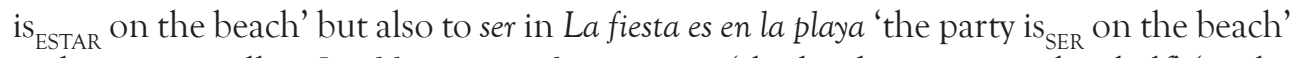
and to ser as well in Los libros son en la estanteria 'the books are ${ }_{\mathrm{SER}}$ on the shelf' (in the sense that this is their intended or allocated place even though they are not there now). Furthermore, they are of no use in resolving cases in which both can be used (Es rojo 'it is SER $_{\text {red' / Está rojo 'it is }}$ ESTAR $r e d$ '; Es alta 'she is SER $_{\text {tall' / Está alta 'she is }}$ ESTAR tall';

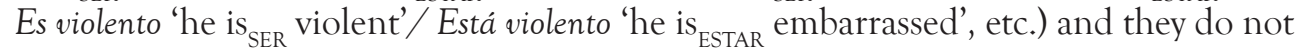
enable us to identify the common link between combinations with estar on the one hand and with ser on the other.

\subsection{Explanations based on the Cognitive Grammar perspective}

From the perspective of Cognitive Grammar there are a number of proposals describing the opposition between ser and estar with attributive values, which is the most difficult to describe: Delbecque 2000, Sanaphre Villanueva 2009, Jurado 2014 
and Romo Simón 2014. With subtle differences, Delbecque and Jurado both draw on the idea that estar is distinguished by its spatial condition. Unlike ser, with estar we locate or situate the subject in the abstract space of the attribute. For Delbecque, ser expresses a categorization in relation to a class of entities. For Jurado, ser characterizes in absolute or immanent terms, as if, visually speaking, we come so close to the object that we can perceive it without actually seeing where it starts or finishes. Sanaphre Villanueva also proposes a conceptualization of far from or near to the object to which we are attributing a property, in which case ser imposes a distant view of the object and estar a close view.

Romo Simón (2014) applies the profile/base distinction (see 2.1.1 for examples of how these concepts are applied) in the differentiation of these two verbs. The author argues that in the uses of estar the attribution of a feature or a property to an object

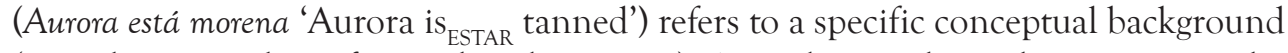
(spatial, temporal or of any other dimension). According to the author, estar puts the background or context to which the attribution is confined into profile (in this case, our previous experience that Aurora has a fair complexion). This background is not relevant when ser is used. With ser an internal attribution is established that does not profile any specific conceptual background, giving rise to a generic reading (Aurora es morena 'Aurora is ${ }_{\mathrm{SER}}$ dark skinned'). See Castañeda and Ortega (forthcoming) for a wider review of these proposals.

The proposal presented below takes into account some of the dimensions considered by the aforementioned approaches (the spatial condition associated with estar or the profile/base distinction), but as we will see in section 2, they are applied differently and they combine with other theoretical concepts and descriptive instruments provided by CG for other descriptive problems that do not concern us here.

\section{Other possible applications of CG to the ser/estar distinction.}

\subsection{Instruments of description}

Further to the concepts applied in Delbecque, Jurado, Romo Simón and Sanaphre Villanueva, we believe that there are a number of additional theoretical tools with which CG can help solve some of the problems uncovered in the approaches described above. These tools include: (a) the profile/base distinction, (b) the notion of grammaticalization through attenuation, (c) the active-zone concept, (d) the mechanism of subjectification and finally, (e) the conception of syntactic 
and dependency relations on the basis of correspondences between the semantic components of the constituent signs of a construction. We will examine each of these aspects below. We include here, in part, the review of all these aspects undertaken in Castañeda and Ortega (forthcoming) and Alhmoud and Castañeda (2015).

\subsubsection{Profile/Base.}

According to this distinction of CG (see, for example, Taylor, 2002: 192-194, Langacker, 2008: 66-70 or Maldonado, 2012: 225-226), of all the aspects involved in a particular scene, we designate some (those which make up its profile) and view the others as the conceptual environment that is necessarily presupposed but not designated (the aspects that make up its base). The words designating the various parts of a set are a clear example of this. In them, the designated part is the profile and the set of which it is a constituent component or the function with which it is associated are the base. So, for example, with the word manga 'sleeve' we designate the flexible cloth cylinder open at both ends (profile) that is part of a garment and in which one of our arms is inserted (base). The notions of garment and arm are part of the meaning of manga but only on a secondary plane, as a background conceptual domain.

This distinction can also be recognized in grammar. As such, in all the elements with deictic value, the people involved in the utterance - speaker and hearer-, the time and space of the utterance - designated respectively by the adverbs ahora 'now' and aqui 'here'-, which act as reference elements with regard to which events and objects are situated, make up the presupposed but not designated base of their meaning. With demonstratives, for example, we designate objects that we place in relation to the space of the speaker: este 'this' designates an object that is situated within the space of the speaker, ese 'that' an object that is outside the space of the speaker (prototypically that of the listener) and aquel 'yonder' an object that is outside and far away from the space of the speaker (and prototypically of the listener). In all three cases the reference spaces form the base, and the indicated object makes up the profile.

Another example, amongst many possible alternatives, is the meaning coupled to the periphrasis of estar + gerund. We use this structure to designate the intermediate stage (profile) of a process (base). In addition, the passive participle designates the state (profile) resulting from a process (base). In fregado 'mopped' or arreglado 'fixed' the processes of mopping or fixing are not designated as such, but these are necessarily presupposed as a background notion (base) against which the designated state (profile) stands out.

As we will see later, some of the features associated with estar can be reinterpreted in relation to this distinction: for example, the individual norm of reference associated 
with the predicates constructed with this copulative verb would constitute the base in relation to which the situation in which the subject finds itself is designated. Thus, unlike ser, estar, used attributively, it links the subject to a condition that presupposes, but does not designate, other prior and/or subsequent conditions or stages in the base.

\subsubsection{Grammaticalization through attenuation.}

The process of grammaticalization (Cuenca 2012) through attenuation (Langacker 2009: 103-107) helps us understand how certain lexical elements change their meaning and function acquiring more abstract values. This is what has happened, for example, to certain verbs of motion (ir 'go', venir 'come', andar 'walk'), which have become auxiliaries of periphrases in which the original locomotive meaning has given way to a temporal interpretation (Va a dimitir 'he/she "goes" (is going) to resign'; Vienen ocurriendo cosas extrañas desde entonces "strange things "come" (have been) happening since then', Anda diciendo que son novios 'he/she "walks" (is going around) saying they are a couple', etc.). Langacker (2000: 309-312) applies precisely this idea to explain the conversion into an attributive or auxiliary verb of the verb estar, whose original meaning in Latin was 'to stand somewhere'. Although initially the verb estar had a locative sense, the process of grammaticalization through attenuation has resulted in the relegation of the spatial location presupposed by estar to the base. This helps understand why what at first was a secondary predication, such as tumbado 'lying down' or aburrido 'bored' in

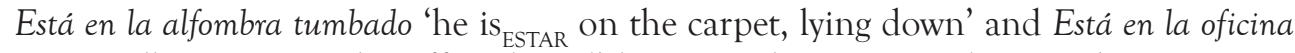

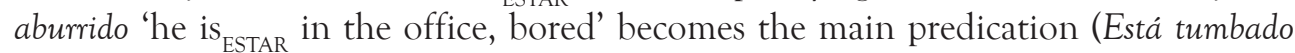
'he is ESTAR $_{\text {lying down'; Está aburrido 'he is }}$ ESTAR bored') describing a state concomitant with an unspecified or only vaguely presupposed spatiotemporal coordinate.

\subsubsection{Active zone.}

The active zone (Langacker 2008: 331-334) is a type of metonymy that is present in different classes of grammatical relations. It is a case of metonymy in which we refer to the part by mentioning the whole. When we say Átate los zapatos 'tie your shoes' (author's example) we are not really telling the person to make a knot that joins their shoes together but rather to tie their shoe laces. The laces would be the active zone of the shoes in this relation, the real object affected directly or immediately by the action of tying. The active zone is therefore the component of a complex semantic structure that intervenes directly in the relation with another entity expressed by some type of predicate. If we say Se afeitó 'he shaved (himself)', although the reflexive construction expresses the coincidence between the subject and the direct complement, it is clear 
that the shave does not have to be all-inclusive. The reflexive construction is used metonymically alluding to the whole (the person) to refer to a part (the beard).

As we will see in section 2.2.2 this type of metonymy can be seen in both the attributive and the locative uses of ser.

\subsubsection{Subjectification.}

In contrast to the objective form of representation, which is the canonical option from a logical point of view, there can also be a subjective way in which we represent the facts to ourselves not in terms of what is determined in them but rather in terms of the mental processes we experience in the process of conceptualizing them. Subjectification (Langacker, 1987: 128-132) occurs when we talk about the world as if things were happening that in reality only happen in our minds when we represent the world to ourselves. Subjectification occurs, for example, (a) when we talk about movement in the mental scanning of the extent of things and not their objective movement (La carretera va desde la playa hasta la casa 'the road goes from the beach to the house', La colina se eleva suavemente 'the hill rises gently') or (b) when we talk about the episodic, bounded or one-off nature of our mental experience and not about the situations referred to, which may be static and non-bounded (Apareció de pronto una señal en el cruce y no pude parar a tiempo, 'a sign suddenly appeared at the junction and I couldn't stop in time', El paisaje fue precioso 'the scenery was ${ }_{\text {SER }}$ beautiful'. In section 2.2.1 we will see that some aspects of the attributive use of estar can be explained using this notion.

\subsubsection{Syntactic relations and correspondences}

In CG (Langacker 1987, 1991), the syntactic relations between the components of a phrase are understood as links in the plane of the signifier (contiguity in word order or morphological matches) that symbolize links or correspondences between different semantic aspects. In Alhmoud and Castañeda (2015) the mechanisms involved in these relations were explained with the example Un hombre escalaba una montaña 'A man was climbing a mountain'. We have included this illustration in this paper, so as to be able to refer to it when we apply the same descriptive instruments to constructions with ser or estar.

Figure 2 shows a number of important aspects related to the conception of grammatical relations characteristic of CG. Figure 2 shows how both the phonological and semantic poles of the linguistic signs that form part of the sentence combine and integrate, be it at morphological or syntagmatic level, which in CG are considered to be qualitatively the same thing. 
Figure 2: Dependency relations and semantic integration through correspondences of semantic subcomponents

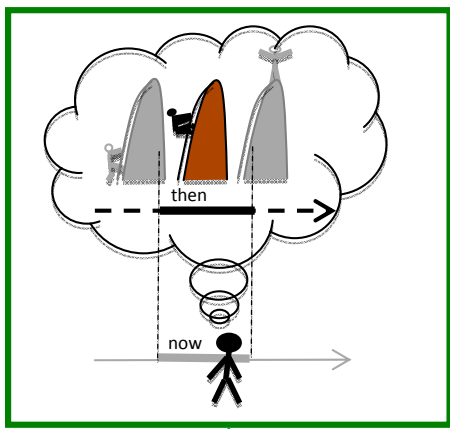

Un hombre ('a man') escalaba ('was climbing') una montaña ('a mountain')

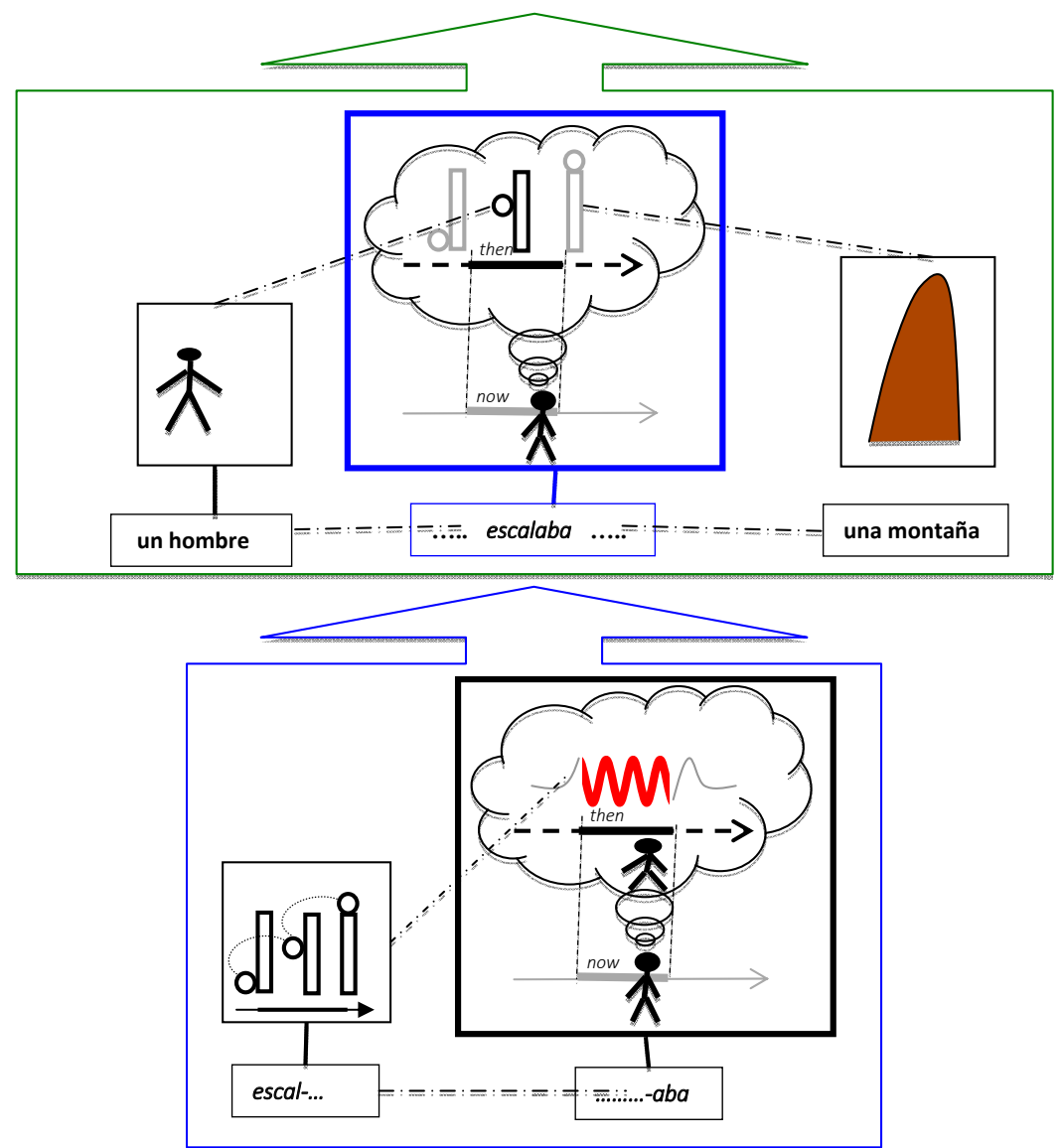


The symbolic relations exemplified here are shown by means of the connection of a phonological component (reduced here to a merely literal transcription) framed by a rectangle at the bottom and a semantic component also framed by a rectangle at the top, as shown in Figure 3.

Figure 3: Symbolic nature of language signs

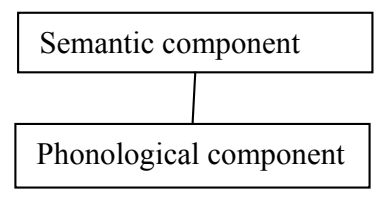

To avoid the analysis of the example becoming very complex, we have not represented the contribution made by the indefinite articles that accompany the nouns hombre 'man' and montaña 'mountain'. The first step of integration (surrounded by a blue arrow-rectangle) shows the way the imperfect morpheme [.......-aba] combines with the verb root of escalar 'climb' [escal-...]. It reflects, on the one hand, the association of the imperfect tense ending with the abstract semantic configuration that is supposed to characterize it here and, on the other, the relation between the verb root of escalar and its meaning. As for the root of the verb escalar, in phonological terms it is indicated that, like the rest of the verbal lexemes in Spanish, it is not a free form. The ellipsis following the lexeme indicates that it must be combined with another morpheme. The meaning of the verb is shown as suggested in Langacker (1987: 311), as normally used in CG: as it is a verbal morpheme, it designates a process, i.e. a relation that is perceived in its temporal validity or development (hence the arrow pointing to the right, which we highlight because the sequential representation of the relation described is useful for distinguishing verbs from other classes of words) $)^{2}$. In this case the complex spatial relation (changing in time) between two objects is designated, one of which, the main figure or trajector, represented by a circle, moves vertically along one of the sides of the other, the secondary figure or element of reference (landmark), represented by a rectangle. The situation is shown as if captured in three "snapshots" that summarize the development of the "climber's" position. The two dotted arcs connecting the three circles are intended to indicate that it is the same object captured at three different moments in succession. As the verb root is not accompanied at the moment by a nominal phrase clarifying who or what the subject is and what the direct object of the verb is, i.e. what specific entities play the roles of climber (main

2 Some classes of words presuppose time as a component of their semantic structure but do not place it in the foreground of their profile, as occurs with past participles, which behave like adjectives despite presupposing the occurrence over time of the process whose final stage is designated. The process that has resulted in that final state in which the patient of roto [broken], cocinado [cooked], examinado [examined], etc. finds itself is present in the meaning of the participle, but remains on a secondary plane in which it is not designated. 
figure) and climbed object (secondary figure or element of reference) these elements are only represented in an abstract manner. The circle and the rectangle representing each element are intended to be very unspecific figurations of the participants in this relation, whose exact nature we cannot know until other expressions add details to the characterization. Moreover, as the verbal root of escalar is considered in isolation from its possible temporal endings, the situation is considered in the abstract, without actualising in regard to the time of utterance or in relation to any epistemic sphere. In this case this location will be provided precisely by the imperfect indicative morpheme $-a b a$.

Meanwhile, it is understood that the imperfect morpheme designates a process that we situate in a non-current sphere -indicated by the cloud emerging from the head of the person standing in the present (now), the speaker/conceptualizer- which we represent to ourselves as a situation that was present then, i.e. as present and ongoing at the moment of our sequential recollection of the events, remembering it, therefore, as not completed at that moment in the past at which we have mentally situated ourselves $^{3}$. The imperfect morpheme alone cannot express the type of situation to which the utterance refers, it merely contributes a very abstract characterization of the type of entity it denotes, such that the representation of the process that we situate in the present of then is a simple wavy line with which we attempt to evoke the idea of a situation (without specifying any particular feature) that is perceived as underway at that time, but of which only the current phase is captured at the ongoing moment of the sequential reconstruction, i.e. current then. This idea of an ongoing process that is not perceived from beginning to end, is indicated with the distinction of the thick red line of the phase that we perceive as the present of then, and the thin, fainter (grey) line of the initial and final phases, which fall outside the representation carried out by the imperfect.

The broken lines of dashes and dots indicate the correspondence between different components of both the phonological and semantic structures: the meaning of [escal...] is made to correspond with or elaborate on the process only evoked very abstractly by the meaning of the imperfect morpheme. There is also a reciprocal correspondence between the morphs of the verbal lexeme and the temporal morpheme. Both morphs are phonologically dependent on each other to be able to play a syntagmatic role in the core of the sentence: the verbal root requires an ending to integrate into a syntagmatic context and the ending, in turn, requires a base to which to attach itself. The correspondence and integration of the semantic structures is symbolized therefore by the correspondence and integration of the phonological structures. The structure of

3 The conception of the imperfect presented here in summarised form is described in greater detail in Castañeda and Alhmoud (2014b). 
the morphological construction escalaba arises from the set of connections mentioned above, represented in components framed with blue lines.

At the second level of the hierarchical organization of the sentence, included in the green arrow-box, to the right and left of the semantic structure of escalaba, the meanings of un hombre [a man] and una montaña [a mountain] are represented. Since these words are both nouns, their profile is non-relational: they designate things. The dotted lines connecting the meaning of un hombre and of una montaña to the main and secondary figures of escalaba indicate the relations of correspondence between the meaning of the nouns and the objects (the one that moves and the one that is moved over vertically) to which the verb refers. These correspondences are equivalent to the dependency relations that define the diathesis of a verb and that in this case indicate that the object that moves and is constructed as the subject or main figure of the verb escalaba is a man, and that the object one of whose vertical sides is moved over by the former and which is constructed as a direct object or element of reference is a mountain. The semantic correspondences are symbolized phonologically by the juxtaposition of the nominal phrases to the verb. In this sentence the verb is preceded by the subject and followed by the direct object. Correspondences are also symbolized by agreement in the third person (of which an abstraction has been made here to avoid overcomplicating the example again). A set configuration arises from the integration of the meanings of un hombre, una montaña and escalaba, according to the dependency correspondences considered, in which the abstract and schematic representation of escalaba is specified or enriched with the content contributed by the phrases un hombre and una montaña such that the meaning of the construction (Un hombre escalaba una montaña) also designates the complex relation over time of two objects, as escalaba does, while characterizing those two objects in a much more detailed and elaborate way, which is shown in the symbolic relation framed in green boxes at the top of the schema. The core of the construction is therefore the verb, since the sentence as a whole refers to a complex relation of a temporal nature, just as the verb does by itself. The thick line of the box around the meaning of escalaba indicates that it is the core of the construction. In this way the core of a syntactic structure is considered as the element whose profile is inherited by the composite structure, or, in other words, the element that designates the same type of entity designated by the construction as a whole. Similarly, in the integration of the imperfect morpheme with the verbal root of escalar it is understood that the imperfect morpheme imposes its semantic configuration on the lexeme and in this sense it would also be understood as the head of the word.

Note (1) that in the example analysed the syntactic categories of subject and direct object are interpreted semantically as the main and secondary figure in the relation 
described by a verb, (2) that the dependency relations are understood simply as correspondences between more schematic components and more specific components of the semantic structures with different signs, (3) that the only presupposed elements are the symbolic relations between the phonological poles and semantic poles of the different signs, and (4) that in the semantic configuration of the different signs a distinction may be made between components that constitute the focus of the designation of the sign, its profile, and components that are part of its base, i.e. the set of notions that are presupposed but not designated. For example, in the case of the imperfect morpheme the designated process itself (shown in red) constitutes the profile while, for example, the notions of ongoing moment of the mental reconstruction of events (then) or of a deictic centre of reference (the now in which the speaker is located) only constitute part of the base, which remains in the background but must necessarily be taken into account to understand the specificity of the designated element.

\subsection{Ser and estar in attributive and non-attributive uses}

In this section we propose a description of the attributive and non-attributive uses of both verbs that takes into account all the assumptions set out in 2.1.

\subsubsection{Estar in locative, attributive and auxiliary uses}

\subsubsection{Locative and attributive uses of estar}

The approach to estar developed here is defended in Castañeda and Ortega (forthcoming) and is based on the approach put forward by Genta (2008). According to Genta, the central meaning of estar is that which alludes to the relation of location, viewed in its temporal validity, between an object and a given space: La niña está en el

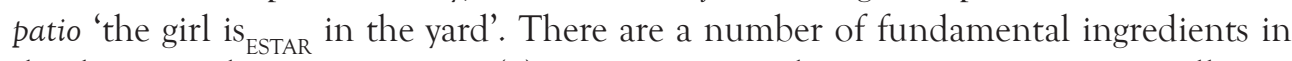
this basic predicative meaning: (1) a static or non-dynamic situation par excellence, characteristic of the non-dynamic locative relation; (2) the prototypical presence of a conceptualizer who perceives or determines the scene episodically or experientially and (3), of equal importance, the possibility of recognising other secondary relations between the subject and certain properties, circumstances, conditions, etc. which are determined as concomitant or contingent to that main situation of location and which can be regarded as predicative: La niña está en el patio sola 'The girl is ESTAR $_{\text {in }}$

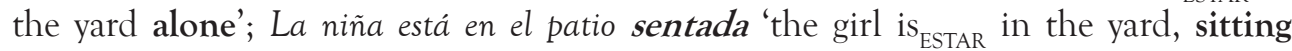
down'; La niña está en el patio aburrida 'the girl is ESTAR $_{\text {in }}$ the yard, bored'; La niña está en el patio jugando 'the girl is $\mathrm{ESTAR}_{\mathrm{E}}$ in the yard playing'; etc. Three possible situations can therefore occur: (1) that we express the mere location of an object in a space, (2) 
that we express the location of an object and also its characterization in relation to that spatial (and temporal) coordinate by means of a predicative complement and (3) we make an abstraction of the spatial location, while still presupposing it, and focus on the characterization of the subject by elevating what at first was only a secondary predicate to a main predicate.

Figures $4 \mathrm{a}, 4 \mathrm{~b}$ and $4 \mathrm{c}$ show diagrams representing the three situations. In all three cases tr equals "trajector", which is identified with the subject (the figure in the relation described by the verb) and $l m$ is the point of reference (landmark), which in this case can be identified with the space in which the subject is located (large circle in bold in $4 \mathrm{a}$ or also the notion expressed by the predicative in $4 \mathrm{~b}$ ). The diagram in $4 \mathrm{a}$ represents the locative value of estar. In the sentences with locative and predicative complements, represented in 4b ( La niña está en el patio sentada) there are two elements of reference: en el patio ( $\operatorname{Lm} 1)$ and sentada ( $\operatorname{Lm} 2)$, this second reference point is represented in $4 \mathrm{~b}$ by the square, which is connected to the subject or trajector (tr) by a broken line. $4 \mathrm{c}$ shows the syntactic pattern corresponding to cases like La niña está tumbada 'the girl is lying down' / de pie 'standing', etc. In them, the space in which the subject is situated is relegated to the base, blurred to the point of being limited to a vague or non-specific presence, therefore disappearing as a landmark. In this case the predicative complement that constituted a secondary landmark becomes the only point of reference in relation to which we characterize the subject. In all three cases, the conceptualizer who perceives or experiences the scene is represented by the circle with the letter $c$ inside. The diagonal lines that come out of it and touch the sides of the thin-lined rectangle represent the perceptive reach of the conceptualization. The conceptualizer is in grey because it is part of the base in these configurations.

Figure 4a: Estar algo (tr.) en algún sitio ( $\mathrm{lm}$.) 'something (tr.) be $\mathrm{ESTAR}$ somewhere (lm.)'

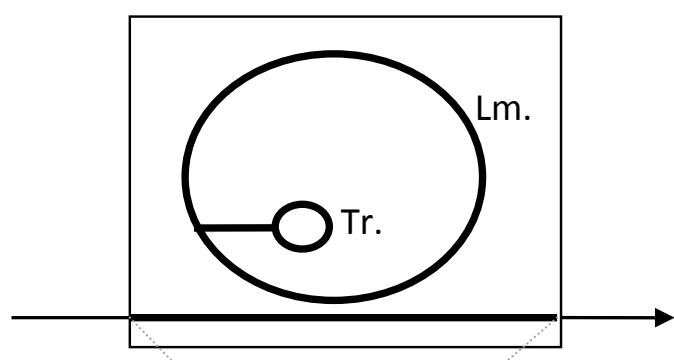


Figure 4b: Estar algo (tr.) en algún sitio ( $(\mathrm{m} 1)$ de alguna manera ( $(\mathrm{m} 2)$ 'something (tr.) be $_{\text {ESTAR }}$ somewhere $(\operatorname{lm} 1)$ somehow $(\operatorname{lm} 2)^{\prime}$
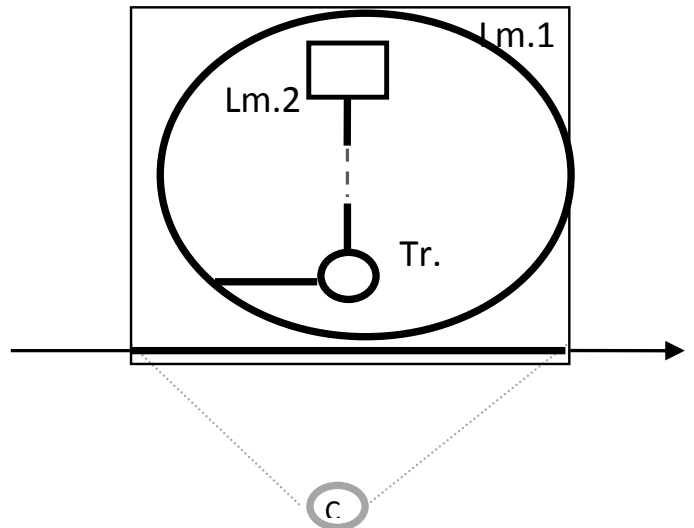

Figure 4c: Estar algo (tr.) de alguna manera ( $(\mathrm{m})$ 'something (tr.) be $\mathrm{ESTAR}$ somehow (lm)'
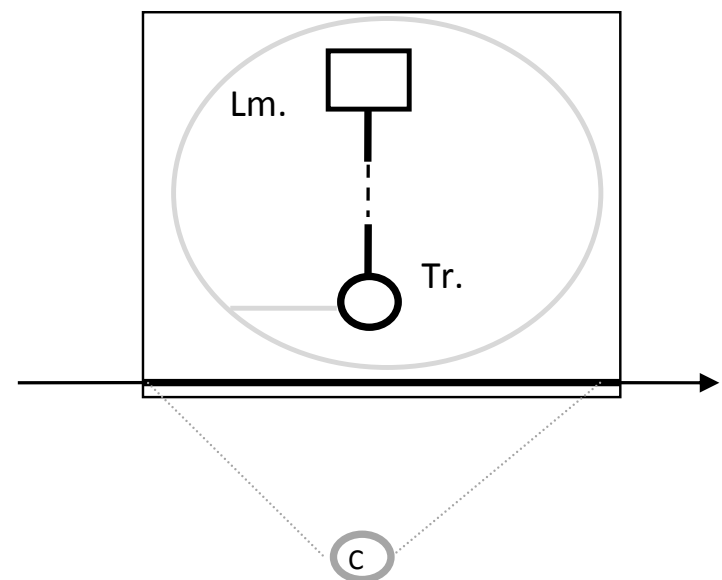

In addition, the arrow pointing to the right at the bottom of the diagrams, with the central part in bold, represents the sequential perception, through their validity in time, of the relations described. The representation of the relation between subject and landmark occurs simultaneously in the space and time dimensions, which are mutually involved. In point of fact, a more accurate representation of the confluence of the two coordinates corresponding to $4 \mathrm{~b}$ would be Figure 5, which shows the stable validity over time of a spatial relation concomitant to a predicative relation. In Figure 5 the iconic notation is also fine-tuned, showing, by means of the connection between the circle (trajector) and the square (entity of some kind that acts as a reference point) which is repeated on the left and right of the diagram and is shown in fainter grey, that the perception of the locative and/or attributive relation that is depicted with estar is 
episodic: it is conceived as a stage that is presupposed to be preceded and/or followed by other stages potentially different from those described. These stages are part of the base, of the conceptual background, presupposed but not designated by estar.

Figure 5: Estar algo (tr.) en algún sitio $(\operatorname{lm} 1)$ de alguna manera $(\operatorname{lm} 2)$ 'something (tr.) be $_{\text {ESTAR }}$ somewhere (lm1) somehow (lm2)'

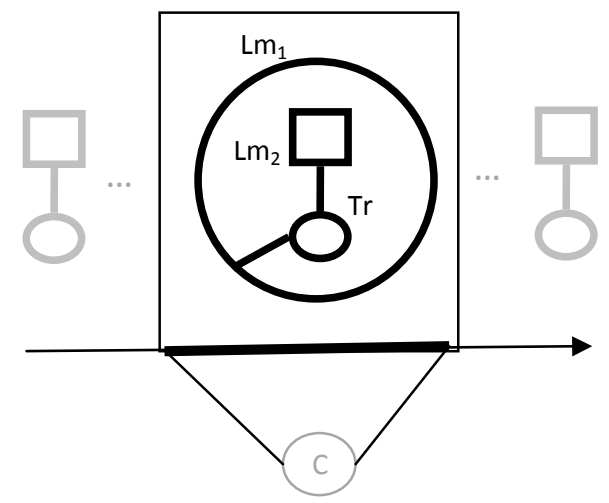

When, by the process of metonymic attenuation, the spatial reference point is blurred, however, the episodic and stable-in-time nature of the relation between the trajector and the predicative reference point remains. The verb estar therefore undergoes a process of grammaticalization by which it moves from being used as a locative predicative verb to being used as an attributive verb with a stative episodic character. Figure 6 attempts to represent the temporal derivation (from the spatial basic value) constituted by its attributive uses, and also that of the use of estar in periphrasis with the gerund.

Figure 6: Estar algo (tr.) de alguna manera 'something (tr.) be $\mathrm{ESTAR}$ somehow (lm1)'

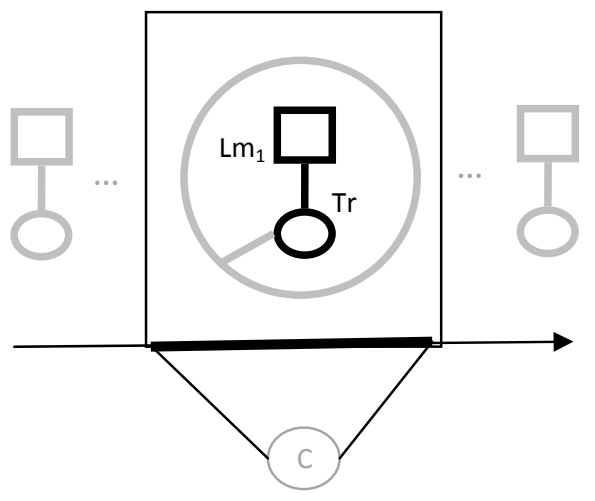


Figure 7 shows the attributive value of estar when there is no trace remaining of the starting configuration other than the stative and episodic nature of the relation. The stages prior or subsequent to the designated stage (framed in a box) are shown in a fainter line because they are outside the profile of the expression. These stages are not designated but are only presupposed in some way.

Figure 7: Attributive estar.

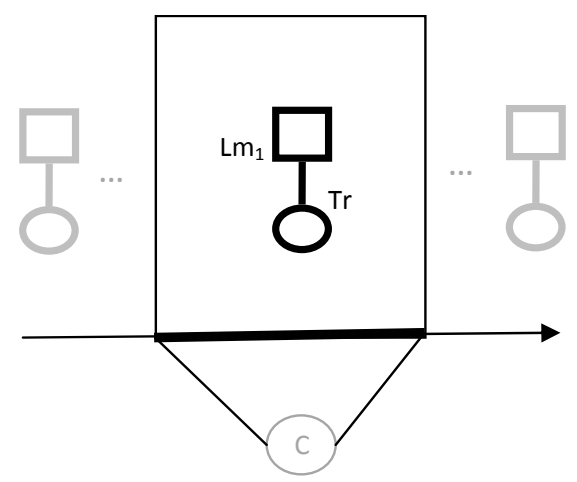

In its copulative use, therefore (La sopa está salada 'the soup is ESTAR $_{\text {salty'; Ramón }}$ está contento 'Ramon is $\mathrm{ESTAR}_{\mathrm{ET}}$ happy'; La perrita está sucia 'the little dog is $\mathrm{ESTAR}_{\mathrm{E}}$ dirty' / sentada 'sitting' / hambrienta 'hungry', etc.), which is derived from the locative, estar retains the episodic and experiential nature of the locational relation, while the space in which an object is situated is now of lesser importance, and the other relations described in these sentences become the centre of attention (perrita-sucia; perritasentada; perrita-hambrienta).

Diachronic data in support of this explanation were found in the study by Marco and Marín (2015). These authors offer statistical data, drawn from an extensive diachronic corpus spanning the 12th to the 20th centuries in support of the hypothesis that the uses of estar in adjectival passives (Ahi están escritas todas las leyes 'there are ESTAR written all the laws = all the laws are written there') as well as in attributives with

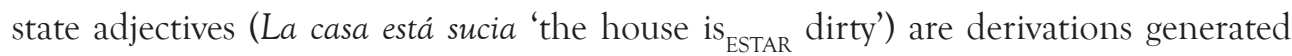
progressively by processes of grammaticalization and analogy starting from the originally locative use of estar. The generalization of estar to locative, passive adjectival or stage level attributive contexts was made at the expense of the use of ser, which was displaced from these values for which it was also originally used until the 13th century. In the early centuries of Old Spanish, ser was the default copulative verb for all situations. With examples adapted from Marco and Marín (2015): la puerta era bien

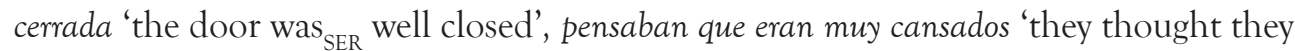
were $_{\text {SER }}$ very tired', donde eran los mojones 'where the milestones were SER $^{\text {'. }}$ 


\subsubsection{Estar in progressive periphrasis with the gerund}

In Castañeda and Ortega (forthcoming) it is suggested that in the use of estar as an

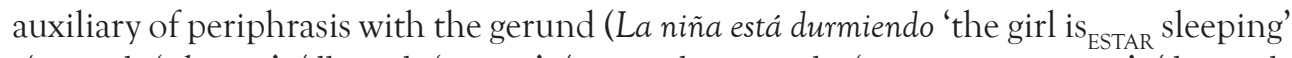
/ jugando 'playing' / llorando 'crying' / pintando un cuadro 'painting a picture' / haciendo los deberes 'doing her homework', etc.), the spatial location is of residual importance or is of a schematic or abstract nature. In this case, the secondary relation that takes centre stage has a quasi-verbal character, corresponding to the gerund, which, added to the features of estar, results in what we know as progressive periphrasis. We will develop this idea in the following paragraphs.

The gerund designates a relation in which the subject is involved, seen through its non-bounded temporal development which is simultaneous with another main situation that can be temporally actualized (subir andando 'go up walking = walk up'; conducir hablando por teléfono 'drive talking on the phone', ducharse cantando 'take a shower singing', etc.). The adverbial relational nature of the gerund in Spanish (it always refers to a verbal predicate to which it is subordinated) is depicted in Figure 8, taken from Genta (2008: 84). In the figure the red circles represent an agent of unspecified nature that causes a change of state in another object in which it gradually turns a certain colour (blue in the figure). This action is presented as simultaneous and concurrent to another situation in which the agent is also involved but which is not specified, which is suggested by the rectangle and the broken nature of the line that expresses the relation. Only when the gerund is combined with a temporally actualizable verb is the nature of that main situation specified, as in Trabaja pintando 'he/she works painting = he/she paints for a living'/ Se divierte pintando 'he/she enjoys (him/herself) painting' / Viaja pintando 'he/she travels, painting' / Está pintando 'he/ she is painting'.

Figure 8: ... pintando 'painting'

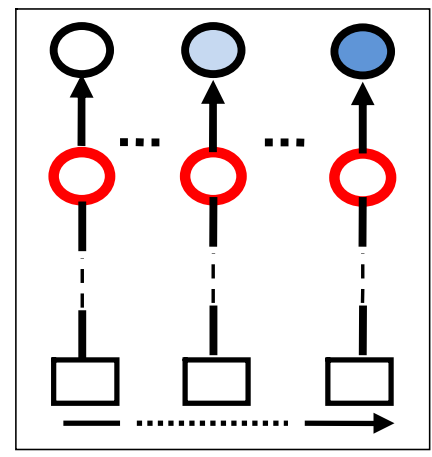


Alternative and more iconic representations of the combination of a gerund and a main verb that is complemented by it are shown in Figure 9a for the specific case of subir las escaleras andando 'go up the stairs walking = walk up the stairs'.

Figure 9a shows the combination of the main predicate (subir las escaleras 'go up the stairs') and the gerund (andando 'walking'), maintaining a separate representation of each component and indicating the relations of correspondence (indicated by dotted curved lines) that occur between the semantic configuration of each. The bolder line of the rectangle surrounding the conception associated with subir las escaleras indicates that the head of the combination, the component that imposes its profile on the set, is the predicate subir las escaleras.

In the meaning of andando we have identified two components, labelled $\mathrm{lm}$ (landmark) and tr (trajector). The landmark iconically and synthetically represents a dynamic situation in which a man displaces himself by moving his legs; this situation is related in turn to another, the trajector, which is not specified and occurs simultaneously in time and with which the situation of walking keeps pace synchronically. The large dotted arc captures this correspondence in the temporal development of the predicate in the gerund and the main predicate. The component corresponding to andando shows therefore that the gerund morpheme imposes a dependent relational structure on the lexeme andar 'to walk' in which the subject of andar also participates in another situation described only in very non-specific terms and which is therefore variable: hablar 'talk' / subir 'go up' / leer 'read' / etc. andando 'walking'. The schematic nature of the main predicate (the trajector) with which the gerund is to be combined is suggested by the relation (vertical broken line), seen over time (arrow pointing to the right) of an object (circle) with any entity (rectangle). In addition, the small dotted arc indicates the correspondence or identity between the subject of andando and the subject of the predicate to which it is subordinated (which will also prove to be the subject of subir). Another dotted arc indicates the correspondence between the main situation (trajector) to which the gerund andando refers, described only schematically in the structure of the gerund, and the more specific and detailed situation to which subir escaleras refers. When the gerund combines with the predicate subir escaleras, the more concrete meaning of the latter predicate elaborates the trajector component of the gerund. In the configuration corresponding to the overall construction (subir escaleras andando 'go up stairs walking') the representation of the construction is presented in an integrated manner. The fainter colour of the figures representing the movement of andar and the bolder colour of the stairs and of the upwards movement that occurs along them suggest, respectively, the subordinate nature (in the sense that it is relegated to a secondary plane of the base) of the predicate in the gerund and the dominant role (in the sense that it imposes its profile on the whole) of subir escaleras. 
Figure 9a: Integration of subir escaleras 'go up stairs' with andando 'walking'

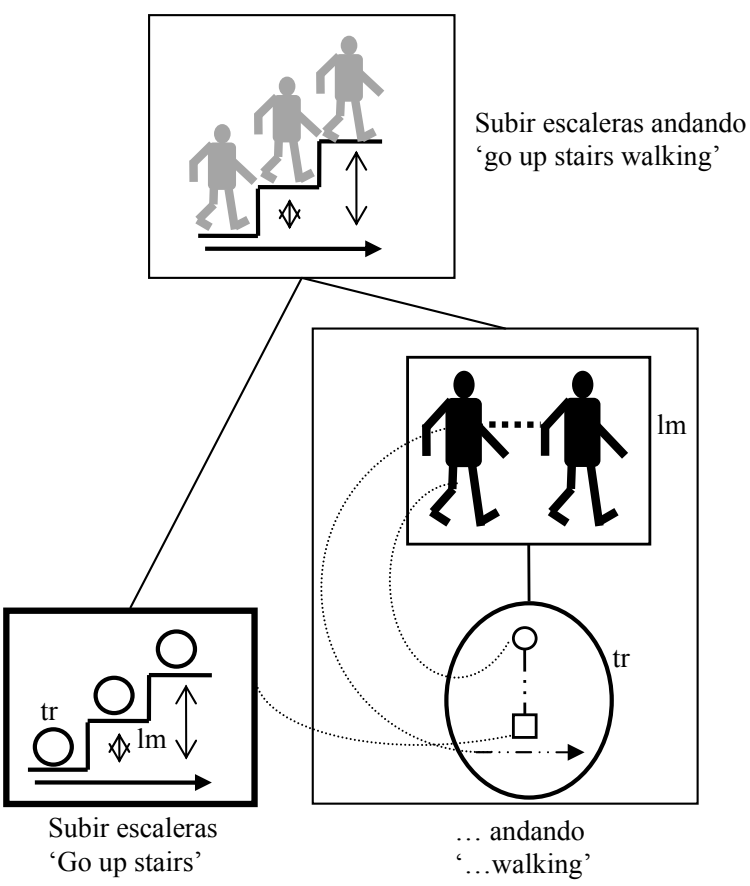

Figure 9b, which corresponds to the expression andar subiendo las escaleras 'walk going up the stairs', shows the inverse situation to that described in Figure 9a: the highlighted component is now that of the figure that displaces itself by walking, and the attenuated component is that of the upward movement along the stairs. In this other case, the predicate that imposes its profile and acts as a head is not subiendo las escaleras but rather andar. 
Figure 9b: Andar subiendo las escaleras 'walk going up the stairs'

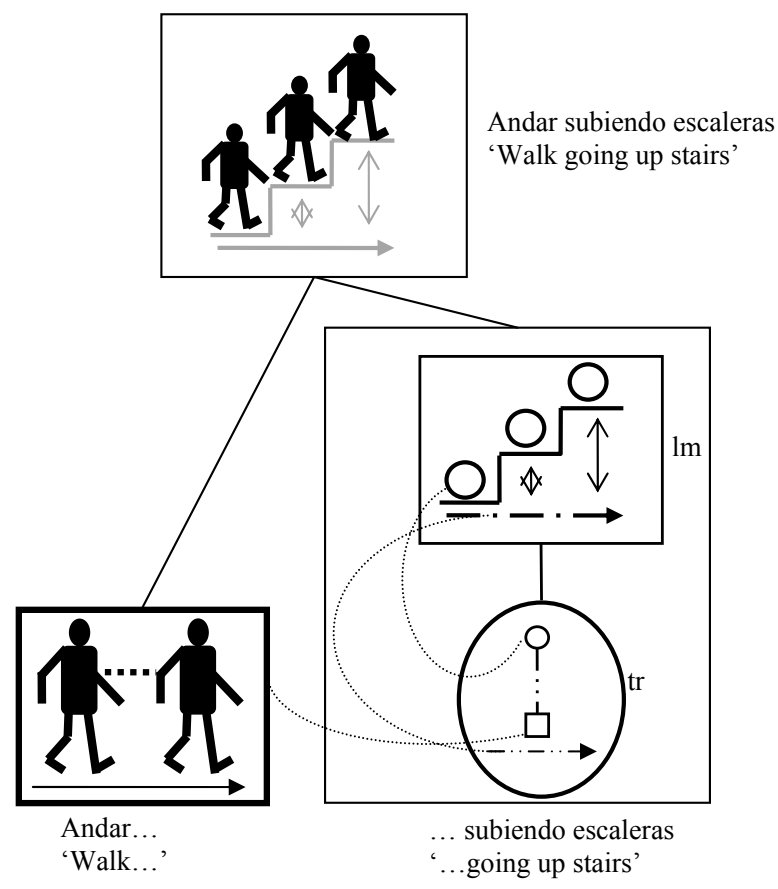

When the gerund combines with estar the former's condition of secondary predicate, corresponding to its adverbial status, is equivalent to that of other complements, as can be seen in the examples La niña está en el patio sola 'The girl is $_{\text {ESTAR }}$ in the yard alone' / sentada 'sitting' / aburrida 'bored' / esperando 'waiting', etc. In its extension to this use as an auxiliary, estar, meanwhile, it retains its designation of state and its episodic nature and is differentiated from the simple attributive role, as a distinctive feature, by its progressive and dynamic quality. The representation of estar (progressive auxiliary) in Figure 10 shows this distinctive feature by means of the dual character of the intermediate state placed in profile, with which we are trying to suggest the idea of a situation in progress. 
Figure 10 represents the integration of the gerund with estar in the progressive periphrasis with the example estar andando 'be $\mathrm{ESTAR}_{\mathrm{T}}$ walking'.

Figure 10: Integration of estar and the gerund in the progressive periphrasis: Estar andando 'be $\mathrm{ESTAR}_{\mathrm{R}}$ walking'.

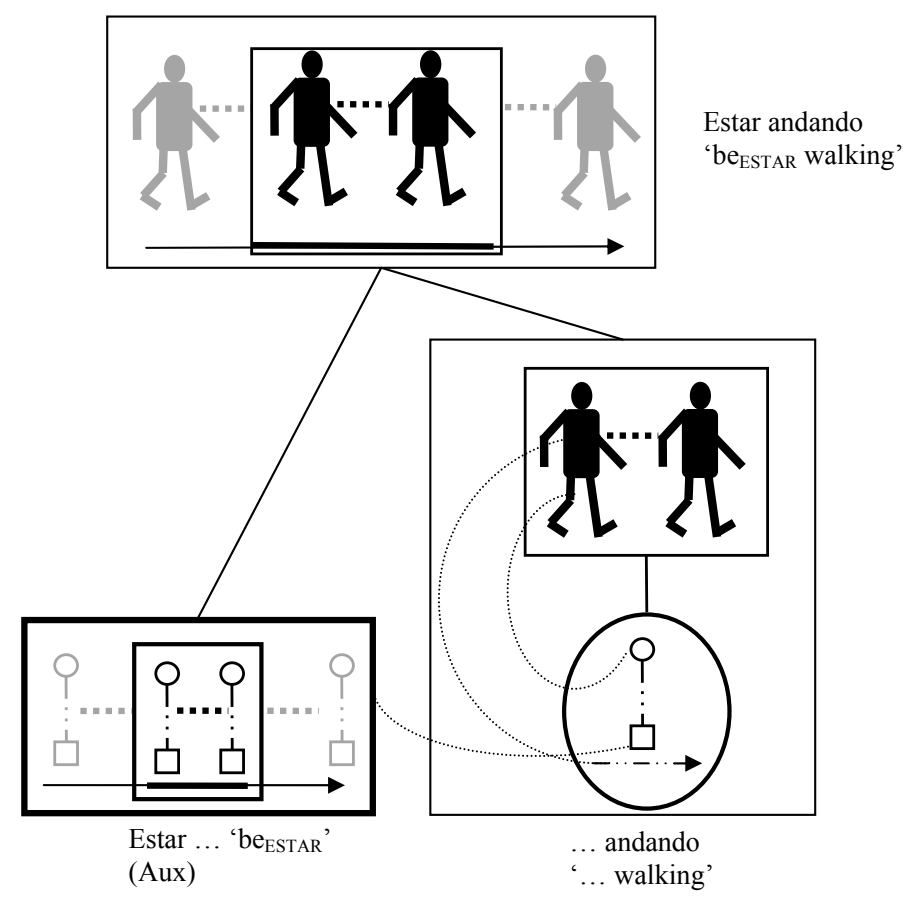

If the main predicate is subir las escaleras 'go up the stairs' the result of the integration is that shown in Figure 9a. If the main predicate with which the gerund combines is the verb estar the only elaboration it contributes is that of the progressive episodic character as well as the possible temporal actualization contributed by estar, but the meaning of estar is so unspecific in relation to other aspects that the only lexical contribution that is not merely configurational is that of the root of andar. This lack of specific conceptual contribution is identified with the grammaticalization of estar, which is categorized in this context as an auxiliary verb or a support verb of the aspectual, temporal and modal specifications. As occurs when the gerund is combined with other kinds of predicates, here estar is also the component that imposes its profile as a temporally and modally actualizable verb. 


\subsubsection{Estar in adjectival passives.}

There is a clear difference between passive constructions known as verbal,

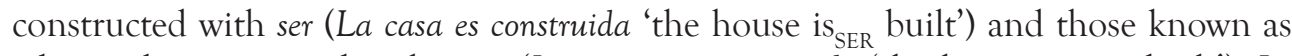

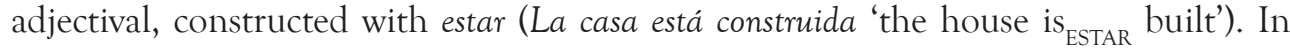
the former, what is focalized is the process itself by which a patient subject undergoes a certain change caused by an agent or more specifically by an agent complement introduced by the preposition por [by] (La casa es construida por los albañiles 'the house is $s_{\text {SER }}$ built by builders'). In the latter (El pollo está cocido 'the chicken is $s_{\text {ESTAR }}$ boiled' / La

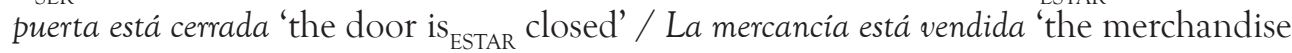

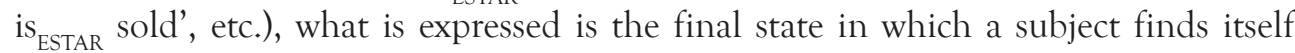
after undergoing (as a patient) a certain process, the result of which is indicated by means of the passive past participle. In these other constructions the process itself is presupposed (it is relegated in the base) and the result is focalized. In view of the comments made thus far on the attributive uses of estar or its function as an auxiliary in the progressive periphrasis, it is not difficult to fit its use in this type of passives into the basic characterization of this verb as a grammaticalized element because the basic idea of location in a state that presupposes different previous states or phases can again be recognized. The distinctive feature that allows us to speak of passive meaning in these cases is not given so much by estar as by the meaning of the participles with which it combines, which result in the passive interpretation if they imply that the presupposed process was caused in the subject by an unidentified agent.

Note that the meaning of the whole that results from combining estar with different types of complements gives rise to seemingly disparate values. In the progressive construction the affected entity is situated in the intermediate stage of a process (Están construyendo las casas 'they $\operatorname{are}_{\text {ESTAR }}$ building the houses'); in the passive construction the affected entity is situated in the final state of a process (Las casas están construidas 'the houses are ${ }_{\text {ESTAR }}$ built'). However, there is a stative and episodic value that can be recognized as a common denominator not only in these two cases but also in the merely attributive values of this verb, as explained above.

Figures 11a, 11b and 11c attempt to capture some important differences between the active version (alguien pinta algo 'someone paints something') the verbal passive

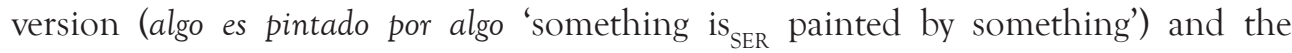
adjectival passive version (algo está pintado 'something is $s_{\text {ESTAR }}$ painted'). The major difference between the first one and the other two, in relation to the way the process of painting present in them all is represented, is that in the active version the agent is the main figure or trajector (red and labelled tr) and the patient is the secondary figure or landmark (labelled $\mathrm{lm}$ ), whereas in the passive versions the main figure is the patient (tr, red) and the secondary figure $(\mathrm{lm})$ is the agent. In addition, unlike the active 
version and verbal passive version, in the adjectival passive version the relation that is conceived as a situation that is perceived sequentially in time (bold arrow pointing right) and is subjected to temporal actualization by means of inflectional morphemes is not the process of painting in itself but the episodic attributive relation between the subject and the condition of pintado 'painted'. Thus we account for the fact that in this case, unlike estar in the progressive periphrasis with the gerund or ser in the analytical passive, which should be considered fully grammaticalized as auxiliaries, in adjectival passives estar appears to function fully as a copulative verb. Finally, Figure 11c shows that, of the process of painting, only the final state in which the patient remains after undergoing the described action continues in the foreground of the profile (more vivid red line). The previous stages and the intervention of the agent are relegated to the base.

Figure 11a: Active. Algo (tr) pinta algo ( $(\mathrm{m})$ 'something (tr) paints something (lm)'

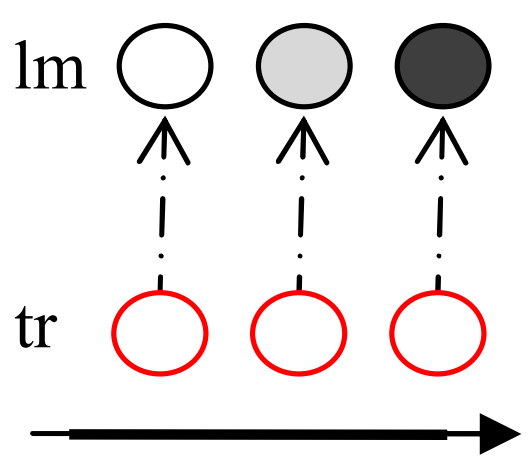

Figure 11b: Verbal passive. Algo (tr) es pintado por algo (lm) 'something (tr) is SER $_{\text {. }}$ painted by something (lm)'

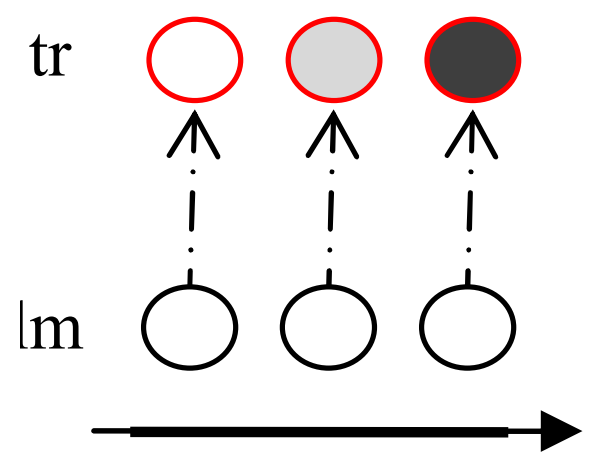


Figure 11c: Adjectival passive. Algo (tr) está pintado (lm) 'something (tr) is ESTAR $_{\text {painted }}$ $(\operatorname{lm})^{\prime}$

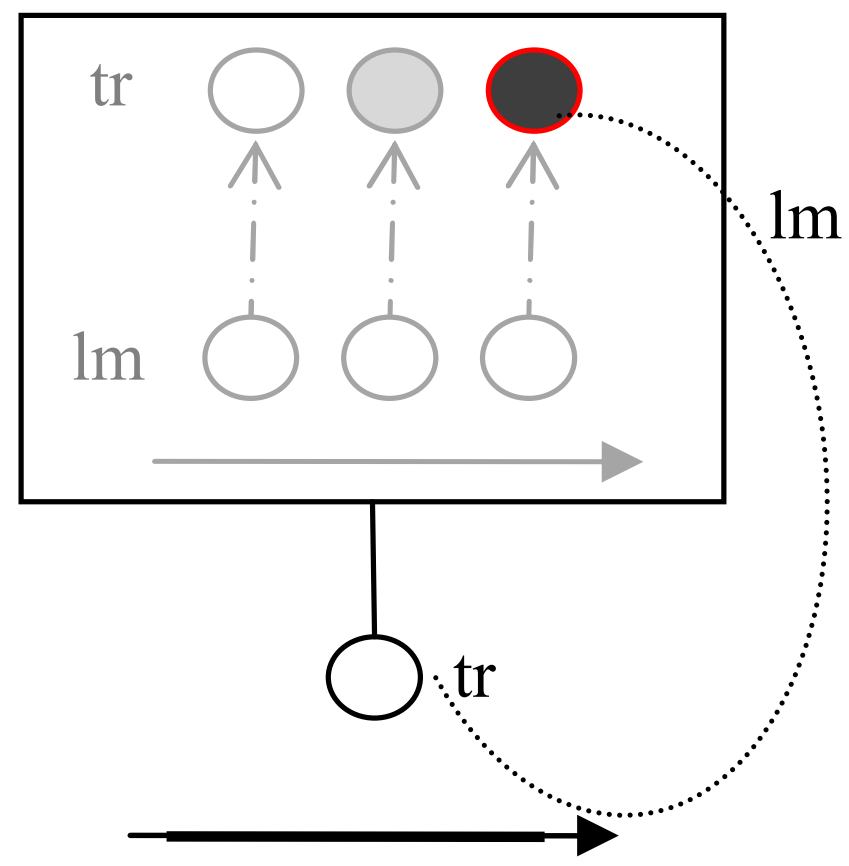

The stative, episodic and experiential character of estar in its attributive uses may be applied by means of different classes of metonymic and metaphoric processes. This helps us to understand the way the meaning of certain adjectives changes when combined with estar or with ser. As in the following cases: ser listo 'intelligent' / estar listo 'ready'; ser verde 'green in colour' / estar verde 'unripe, immature'; ser molesto 'annoying' / estar molesto 'upset'; ser violento 'violent' / estar violento 'embarrassed, uncomfortable'; ser atento 'solicitous, friendly' / estar atento 'paying attention'; ser vivo 'lively' / estar vivo 'alive'; ser malo 'bad' / estar malo 'ill'; es abierto 'frank, outgoing' / estar abierto 'not closed'. Although there are a variety of metaphoric or metonymic processes involved in the reinterpretation of these adjectives when they combine with one verb or the other, it is important to note that the episodic, stative character of estar can be observed in all the cases in which it intervenes.

\subsubsection{Ser in attributive, locative, predicative and auxiliary uses}

The verb ser is used with highly disparate values that are difficult to reduce to a basic single meaning. In addition to (1) its attributive value (Ese jugador es rápido 'that

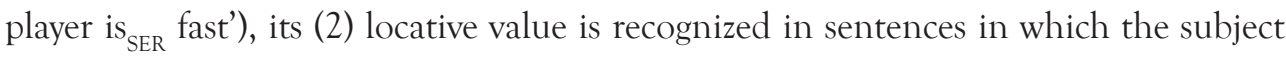




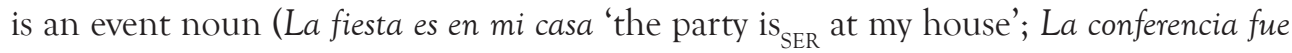

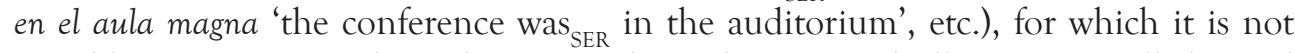
possible to use estar, and in other cases where objects are ideally or potentially located (Los libros son en la estantería 'the books are ${ }_{\text {SER }}$ on the shelf) the offices or the location of an institution, premises, etc. (La policía es en la otra calle 'the police(station) is $\mathrm{SER}_{\text {on }}$ on

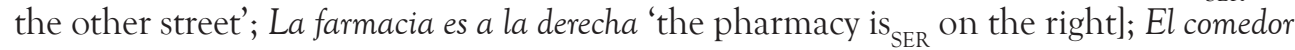
es al fondo del pasillo 'the dining room is SER $_{\text {at }}$ the end of the corridor', etc.) and (3) its value as an auxiliary in periphrastic passive sentences (La manifestación es disuelta por la

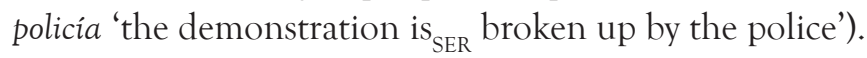

\subsubsection{Ser in attributive uses}

Castañeda and Ortega (forthcoming) defend the idea that, with ser, with regard to its attributive values, in contrast to the copulative use of estar, the establishment of a relation between an object and a certain value of a domain or dimension, the assignment of a property to an object or the inclusion of an object in a certain category

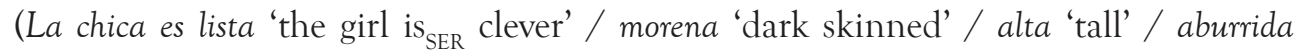
'boring' / pediatra 'a paediatrician' / sudamericana 'South American' / etc.) does not presuppose, even on a secondary plane, the circumscription of that relation to a spatial or experiential sphere. The only temporal limit is that which is expressed through the temporal morphological verb ending, because the verbal character of ser allows us to perceive that relation in its epistemic-temporal development (La chica es / ha sido / era / fue lista 'The girl is SER $_{\text {/ has been }}$ SER $_{\text {/ }}$ was $_{\text {SER }} /$ was $_{\text {SER }}$ clever'). But the internal temporal development of the relation is not relevant, so to speak, nor does it presuppose any evolution or potential change in the base. With ser we establish an identification between the subject, the figure or trajector of the relation, and a reference point (or landmark), the conceptual domain that we express with the attribute. With ser we express an equation between the subject and attribute. The absolute nature of this attribution can be represented, as in Castañeda and Ortega (forthcoming) in Figure 12. The dotted line that connects the trajector or subject and the landmark or attribute is intended to indicate the relation of equivalence or correspondence. 
Figure 12. Attributive ser. Algo (tr.) es algo (lm.) 'something (tr.) is $\mathrm{SER}_{\mathrm{S}}$ something (lm.)'

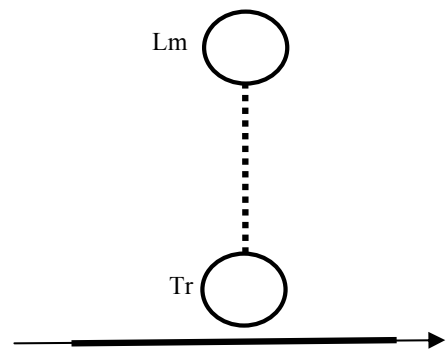

In this conception, therefore, it is understood that the basic value of ser as an attributive verb is to express the correspondence ${ }^{4}$ or equivalence between two entities, one functioning as a figure and the other as an element of reference. This correspondence can come in two forms: (1) strict, such as when we identify the referent of one expression with that of another (Puccini es mi gato 'Puccini is SER $_{\text {my }}$ cat', La tierra es el tercer planeta del sistema solar 'Earth is ${ }_{\mathrm{SER}}$ the third planet of the solar system') or when we define something (Un gato es un felino doméstico 'A cat is SER $_{\text {. }}$ a domestic feline', Un planeta es un astro sin luz propia que gira alrededor de una estrella 'a planet is ${ }_{\text {SER }}$ a celestial body with no light of its own that revolves around a star') or (2) partial or metonymic, such as when we classify something (Puccini es un gato 'Puccini is $_{\text {SER }}$ a cat', La tierra es un planeta 'Earth is ${ }_{\text {SER }}$ a planet') or we attribute properties to it (Mi gato es blanco 'my cat is SER $_{\text {white', La tierra es azul y blanca 'The Earth is }}$ SER blue and white'). Figures 13a, 13b, 13c and 13d, also taken from Castañeda and Ortega (forthcoming), attempt to represent these correspondences and their different nature (strict or metonymic) in simplified form. The sets of semantic specifications are summarized with labels $(\mathrm{P}=$ Puccini, $\mathrm{C}=$ gato 'cat', $\mathrm{F}=$ felino 'feline', $\mathrm{Gr}$. = gris 'grey'). The meaning of "doméstico 'domestic"” is represented iconically with a drawing of a house. The dotted lines represent the correspondence between trajector and element of reference. They are curved in cases of strict correspondence or identity (13a and 13b). They are straight in cases of partial or metonymic correspondence (13c and $13 \mathrm{~d}$ ). In the latter case, the correspondence is partial because the identity occurs between a component of the trajector (in grey), i.e. its active zone, and the reference point. In the case of the diagram in $13 c$, the intention is to indicate that among the many features that define or characterize Puccini one of them is that it is a cat. The identification of "cat" with Puccini does not complete the characterization of Puccini. The correspondence is partial in this sense. Similarly, the correspondence between "Mi gato "my cat" and "gris "grey" in $13 \mathrm{~d}$ is partial or metonymic given

4 Note that in CG, as shown above in section 2.1.7, the terms that are combined in syntagmas integrate their meanings by means of the correspondences between the different components of their semantic structures. The verb ser explicitly designates precisely this correspondence, perceiving it in its temporal validity. 
that the colour grey is only a recognizable feature of a part of my cat (its hair), not a property I can identify with my cat as a whole.

Figure 13: Correspondences in the uses of ser

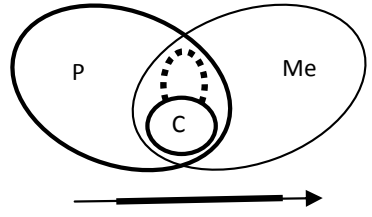

(a) Puccini es mi gato 'Puccini is SER $_{\text {my }}$ cat'.

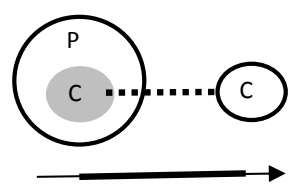

(c) Puccini es un gato 'Puccini is SER $_{\text {a }}$ cat'.

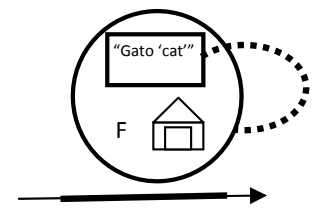

(b) Un gato es un felino doméstico 'A cat is $S_{S E R}$ a domestic feline'.

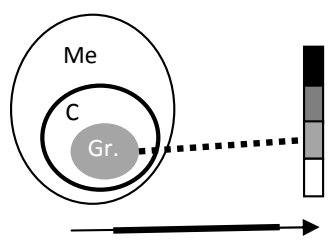

(d) Mi gato es gris 'My cat is SER $_{\text {grey'. }}$.

As Langacker (2008: 332) points out, partial correspondence also occurs habitually in relations between a modifying adjective and a noun: in un coche rápido 'a fast car', una dieta insana 'an unhealthy diet' or una decisión consciente 'a conscious decision', each of the adjectives cannot be attributed directly to the referent of the noun, as rápido 'fast' is predicated from the activity of displacement performed by the car and not of the car itself, insana 'unhealthy' is predicated of the state of health that the diet causes and not of the diet itself, and consciente 'conscious' is predicated of the person who makes the decision, not of the decision itself. So when we say el coche es rápido 'the car is SER $_{\text {fast', la dieta es insana 'the diet is }}$ SER unhealthy' or la decisión fue consciente 'the

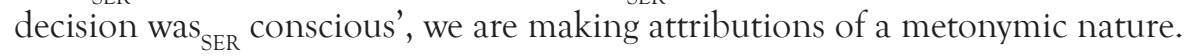

\subsubsection{Ser in locative and passive uses}

Two different types of uses of ser related to the broad functional label of "location" should be taken into consideration.

On the one hand we have the location of events, with subjects related to happenings, to locate them in time or in space (La fiesta es en mi casa 'the party is SER $_{\text {R }}$ at my house', la entrevista será mañana en la oficina de la empresa 'the interview will be $_{\text {SER }}$ tomorrow at the company's offices', etc.), in which the verb is interpreted in 
the sense of 'take place' or 'happen'. There are also uses in which reference is made to the potential or ideal location of an object rather than its real or current use, as in Los miembros del grupo 9 son en esa mesa 'the members of group 9 are at that table', in which we are given to understand that esa mesa 'that table' refers to the table assigned or corresponding to those people.

As for the location of events with ser, the predicative character that is usually assigned to this use relates it in a certain sense to the value it acquires when it is used as an auxiliary in periphrastic passives because in both cases it does not refer to a stative relation, as in attributive constructions, but rather implies the occurrence of an event. It should be noted that these two possibilities also occur in the equivalent verb to ser in other languages that do not have an equivalent to the ser/estar opposition in Spanish. In this sense, the description that may be offered of the eventive uses of ser (both event location and passive auxiliary) may be equivalent to that of to be in English proposed by Langacker (1991: 200-207). The key in this sense, as was indicated above, is to start from the basic assumption that ser, as a verb (albeit in very unspecific or schematic terms but not therefore lacking in semantic content) designates a relation between the main figure (trajector or subject) and the secondary figure or landmark (attribute) that is represented in its temporal development. The fact that the specific character of that relation is not specified in the verb makes the meaning contributed both by the subject and by the secondary figure determine the attributive or predicative nature (either passive or eventive) of the construction. When the subject refers to an event or activity (fiesta 'party', conferencia 'conference', reunión 'meeting', salida 'departure', etc.) the latter imposes its eventive structure and the verb ser, for its part contributing the temporal representation profile, is interpreted in the sense of a happening that can be actualized temporally and modally. For its part, in passives the passive participle contributes the aforementioned profile to a complex relation between a patient that is given the role of main figure and an agent that is relegated to a secondary position. This complex relation in the passive participle, as indicated above, does not put its temporal development into profile, even though it implies development over time. It is ser that provides the representation that puts the sequential view of the relation in the foreground of the profile.

It also seems logical, as Romeu (2015) suggests, that event nouns cannot combine with estar to indicate their location because an event, as such, cannot be separated from the coordinates in which it happens and therefore its location (in time or in space) cannot be dissociated from the event itself or, therefore, alternate or counter other episodic or transitory locations thereof, something which does happen with objects, which can be conceived independently of their locations.

The other type of location with ser has nothing to do with event nouns but rather with objects, in cases like La policía es en la otra calle 'the police is $s_{\mathrm{SER}}$ on the other street', 
Correos es alli 'the post office is $s_{S E R}$ there', La goma es en el lapicero 'the rubber is $\mathrm{S}_{\mathrm{SER}}$ in the pencil case $=$ must be in the pencil case', etc. This use also conveys a metonymical derivation, but different from the one put forward thus far. The structure of examples like these can be understood as equative if we take into account that the nominal phrase that designates the object that is located actually serves to refer metonymically to the location that corresponds to it. That is, it refers to the place a thing occupies simply by mentioning the thing. It is as if we were to say 'la sede de la policía es en la otra calle [the police headquarters is $\mathrm{SER}_{\mathrm{SER}}$ on the other street]', 'el lugar de la goma es en el lapicero [the rubber's

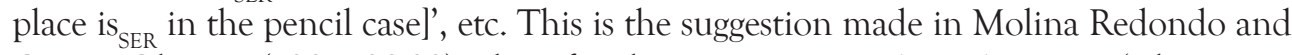
Ortega Olivares (1987: 28-29) when for the question iDónde es el estanco? 'where is SER $_{\text {S }}$ the tobacconist's?' the paraphrase Dónde es donde está el estanco? 'where is SER $_{\text {whe the }}$ where tobacconist's is ESTAR $_{\text {? }}$ ' is proposed. This identification of the place corresponding to a thing is congruent with the sense of instruction implied in these utterances. Note that

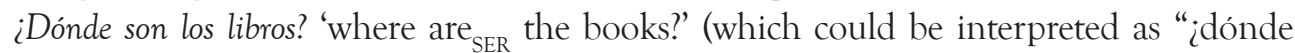
debo poner los libros?" 'where should I put the books?') or Los libros son en la estantería

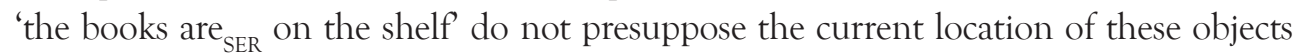
but rather allude to their ideal location, while both ¿Dónde están los libros? 'where are ESTAR the books?' and Los libros están en la estantería 'the books $\operatorname{are}_{\text {ESTAR }}$ on the shelf involve an actual location in a certain place. Uses of this type are also recognized when we place in time: ¿Cuándo soy yo? (¿cuándo es mi turno?) 'when $\mathrm{am}_{\mathrm{SER}} \mathrm{I}$ ? (when is $\mathrm{SER}_{\mathrm{SER}}$ it my turn)', ¿Cuándo son las vacaciones? 'when are ${ }_{\mathrm{SER}}$ the holidays?', etc.

\section{Conclusions}

Our approach to the uses of ser and estar seems to have several advantages over other descriptions:

(1) It shows us that, in attributive cases, the marked element of this opposition is estar, to the extent that it takes on attributive uses in which a stative-episodic component should be presupposed, something that is absent in attributions with ser. It is consonant with the diachronic processes that show how ser has been pushed aside in all cases that include this stative-episodic condition derived from the original locative value of estar.

(2) It accounts better than other proposals for the presence of estar in locatives, progressive periphrasis, episodic attributives and adjectival passives, allowing us to identify the unifying thread that connects them by determining processes of grammaticalization and of metonymic extension, the latter including processes of subjectification that explain cases of an evidential character ( $L a$ miel está dulce

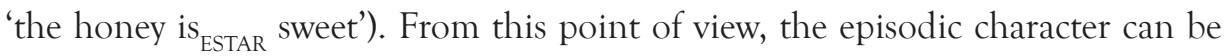


determined even in examples of permanent attribution (Está muerto "he is ESTAR $_{\text {, }}$

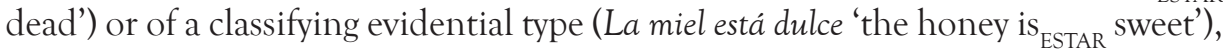
if it is assumed that it is relegated to the background of representation in the base.

(3) It allows us to determine, using the basic concept of correspondence and applying descriptive procedures such as metonymic extension or active zone, a common denominator in the different attributive uses of ser associated with functions as different as identification (Mi perro es aquel 'my dog is $\mathrm{SER}_{\text {SER }}$ that one'), definition (Un flexo es una lámpara de mesa 'a flexo is SER a table lamp'), classification (Los perros son mamiferos 'dogs are $\operatorname{SER}_{\mathrm{S}}$ mammals') or location (Los libros son en la estantería 'the books are SER $_{\text {S }}$ on the shelf').

(4) It makes the integration of eventive (La fiesta es en mi casa 'the party is $\mathrm{SER}_{\text {SE }}$ at my house') and passive (La propuesta fue retirada 'the proposal was SER $_{\text {withdrawn') uses }}$ of ser possible, without needing to assume an irreducible disparity of values, starting from the basic assumption that ser, as a verb, in very unspecific or schematic terms but not therefore lacking in semantic content, designates a relation between the principal figure (subject) and the secondary figure (attribute) that is represented in its temporal development. The fact that the exact nature of this relation is not specified in the verb makes the meaning contributed both by the subject and by the secondary figure (adjective, nominal phrase, prepositional phrase or passive participle) determine the attributive or predicative nature (be it passive or eventive) of the construction.

(5) As suggested in Castañeda and Ortega (forthcoming), the cognitive approach outlined here offers obvious advantages for the development of a teaching version suitable for learning Spanish as a foreign language. For a number of reasons: (1) it allows us to recognize a unifying thread between the different uses of ser and estar that enables an orderly and reasoned conceptualization of the different values; (2) it is based on the premise that each verb is associated to clearly distinguishable meanings and functions and (3) it gives rise to a representation based on images (such as those proposed in Castañeda and Ortega), that helps with recognition and comprehension.

\section{References}

Alhmoud, Z \& Castañeda, A. (2015). Más de gramática, más que gramática. De lingüistica cognitiva y enseñanza de ELE. Revista DOBLELE. Español lengua extranjera. Revista de lengua y literatura. 1. (Universidad Autónoma de Barcelona.). (Available online: http://revistes.uab.cat/doblele). 
Carlson, G. (1977). Reference to Kinds in English, New York: Garland.

Castañeda, A. \& Alhmoud, Z (2014). Gramática cognitiva en descripciones gramaticales para niveles avanzados de ELE. In A. Castañeda (Ed.), Enseñanza de Gramática avanzada de ELE: criterios y recursos. Madrid: SGEL. 39-87.

Castañeda, A. \& Ortega-Olivares, J. (forthcoming). Gramática cognitiva y usos atributivos de ser y estar. In I. Ibarretxe-Antuñano, T. Cadierno \& A. Castañeda (Eds.) Lingüistica cognitiva y ELE. London: Routledge.

Cuenca, M. J. (2012). La gramaticalización. In I. Ibarretxe-Antuñano \& J. Valenzuela (Eds.) Lingüística cognitiva (281-304). Barcelona: Anthropos.

Delbecque, N. (2000). Las cópulas ser y estar. Categorización frente a deixis. In R. Maldonado (Ed.), Estudios cognoscitivos del español. Revista Española de Lingüística Aplicada (Monographic issue). Asociación Española de Lingüística Aplicada. 237-279.

Escandell-Vidal, V. \& Leonetti, M. (2002). Coercion and the Stage / Individual Distinction. In J. Gutiérrez-Rexach (ed.), From Words to Discourse. New York / Amsterdam: Elsevier. 159-179.

Fernández, S. S. \& Falk, J. (eds.) (2014), Temas de gramática española para estudiantes universitarios. Frankfurt am Main: Peter Lang.

Fernández Leborans, M. J. (1999). La predicación: las oraciones copulativas. In I. Bosque \& V. Demonte (eds.). Gramática descriptiva de la lengua española. Madrid: Espasa. 2357-2460.

Genta, F. (2008). Perifrasis verbales en español: focalización aspectual, restricción temporal y rendimiento discursivo. Doctoral Thesis. University of Granada. (Available online: https://hera.ugr.es/tesisugr/17647526.pdf)

Gumiel Molina, S. (2008). Sobre las diferencias entre ser y estar. El tipo de predicado y el tipo de sujeto. Silvia Gumiel Molina. REDELE 13. (Available online: http://www.mecd.gob.es/redele/revistaRedEle/2008/segunda.html)

Gumiel Molina, S. \& Pérez-Jiménez, I. (2012). Aspectual composition in <SER/ ESTAR+ADJECTIVE $>$ structures: adjectival scalarity and verbal aspect in copular constructions. Borealis. An International Journal of Hispanic Linguistics. 1/1 (Avaliable online: http://dx.doi.org/10.7557/1.1.1.2321). 33-62.

Gumiel-Molina, S., Moreno-Quibén, X. \& Pérez-Jiménez, I. (2015). The inference of temporal persistence and the individual/stage-level distinction. In I. Pérez-Jiménez, M. Leonetti and S. Gumiel-Molina (eds.), New Perspectives on the Study of Ser and Estar (119-146). Amsterdam/Philadelphia: John Benjamins.

Jurado, M. (2014). Fundamento teórico de un modelo para trabajar los verbos haber, estar y ser en el aula de ELE. Revista Nebrija de Lingüistica Aplicada a la enseñanza 
de Lenguas. 17. (Available online: http://www.nebrija.com/revista-linguistica/ fundamento-teorico-de-un-modelo-para-trabajar-los-verbos-haber-estar-y-ser-en-el-aulade-ele)

Husband, M. (2012). On the compositional nature of states. Amsterdam: John Benjamins.

Langacker, R. (1987). Foundations of cognitive grammar. Volume I Theoretical Prerequisites. Stanford-California: Stanford University Press.

. (2000). Grammar and conceptualization. Berlin, New York: Mouton de Gruyter.

___. (2008). Cognitive grammar. A basic introduction. Oxford: Oxford University Press. Gruyter.

. (2009). Investigations in Cognitive Grammar. Berlin, New York: Mouton de

Leonetti, M. (1994). Ser y estar: estado de la cuestión. Pliegos de la insula Barataria 1: 182-205.

Llopis-García, R., Real Espinosa, J. \& Ruiz Campillo, J. P. (2012). Qué gramática enseñar, qué gramática aprender. Madrid: Edinumen.

Luján, M. (1981). The Spanish copulas as aspectual indicators. Lingua 54: 165-210.

Maienborn, C. (2005). A discourse-based account of Spanish ser/estar. Linguistics 43 (1): $155-180$.

Marco, C. \& Marín, R. (2015). Origins and development of adjectival passives in Spanish. In I. Pérez-Jiménez, M. Leonetti \& S. Gumiel-Molina (eds.), New perspectives on the Study of Ser and Estar (239-266). Amsterdam/Philadelphia: John Benjamins.

Maldonado, R. (2012). La gramática cognitiva. In I. Ibarretxe-Antuñano \& J. Valenzuela (eds.), Lingüística cognitiva. Barcelona: Anthropos.213-266.

Matte Bon, F. (2000). Gramática comunicativa del español. Tomo II: de la idea a la lengua. Madrid: Edelsa.

Marín, R. (2004). Entre ser y estar. Madrid: Arco Libros.

Pérez-Jiménez, I. Leonetti, M. \& Gumiel-Molina, S. (eds.). (2015). New perspectives on the Study of Ser and Estar. Amsterdam/Philadelphia: John Benjamins.

RAE/ASALE (2009). Nueva gramática de la lengua española. Madrid: Espasa Calpe.

Radden, G. \& Dirven, R. (2007). Cognitive English Grammar. Amsterdam/ Philadelphia: John Benjamins.

Romero, J. (2009. El sujeto en las oraciones copulativas, Verba 36: 195-214. 
Romeu, J. (2015). Ser and estar and two different modifiers. In I. Pérez-Jiménez, M. Leonetti \& S. Gumiel-Molina (eds.), New perspectives on the Study of Ser and Estar . Amsterdam/Philadelphia: John Benjamins. 51-83.

Silvagni, F (2013). ¿Ser o estar? Un modelo didáctico. Madrid: Arco Libros.

Taylor, J. R. (2002). Cognitive Grammar. Oxford: Oxford University Press.

Zagona, K. (2015). Location and estar/ser alternation. In I. Pérez-Jiménez, M. Leonetti \& S. Gumiel-Molina (eds.), New perspectives on the Study of Ser and Estar . Amsterdam/Philadelphia: John Benjamins. 147-172. 